\title{
Guidelines for the economic evaluation of protected areas, implementing environmental protection functions
}

\author{
A. A. Litvinova, M. N. Ignat'eva, L. M. Morozova, M. S. Kubarev
}

The article is devoted to the economic evaluation of environmental protection functions of specially protected areas (PAs), a part of the total value of the flow of services provided by them. The aim of this study is to improve the methodological tools of economic valuation of protected areas, implementing environmenta functions, based on the analysis of methodological approaches to the economic valuation PAs lands, considering the basic features and services of protected areas, identifying of specifics of the flow of ecosystem services within the functional areas of protected areas. Authors analyzed the methodological approach, reflected in the technical and tconomic justification of methodology of state cadastral valuation of land reserves and the Timely method of state cadastral valuation of lands of specially protected territories and objects; disclosed positive and negative aspects of each. The authors proved the feasibility of using mixed methodological approach for the economic evaluation of environmental protection functions of PAs that combines direct assessment method (alternative cost) and indirect one (the establishment of correction coefficients reflecting qualitative characteristics of PAs). One can find the author's methodological recommendations in this article, which present proposals for defining of specific annual standard for average values of PAs land and the establishment of additional coefficients: the uniqueness coefficient of biodiversity at the regional level, coefficient of conservation value of functional PAs land and environmental significance coefficient of PAs. The authors tested guidelines for conditions of the mountainous part of the Khanty-Mansi Autonomous District - Yugra within the boundaries of the district Berezovsky.

Keywords: economic evaluation; protected areas; environmental functions and services; correction coefficients.

\section{ntroduction}

The current stage of development of the Russian system of protected areas typically presents a gradual transition from a model that considers protected areas as an "islands of environmental well-being isolated from the outside world" [1], to the integration model that considers protected areas in terms of integration into the socio-economic development of regions of the country and ensuring of the flow of ecosystem services beyond their borders. The practice of organization and management of protected areas using an integrated approach requires significant changes in the information support in the aspect of the integration of natural resource and environmental resource potentials in the regional economy. This is primarily associated with the need for economic evaluation of natural resources and, especially, ecosystem services (environmental resources) provided by protected areas to different users.

Results and discussion

According to the objectives facing the researchers, the analysis of ecosystem functions carried out by the protected areas shows that the primary ones are conservation functions. In work [2] as parts of these functions, authors allocate:

- standard function, manifesting in the preservation in protected areas of inviolate and intact natural complexes with their inherent internal biological diversity;

- refugium function, that consists in preservation of rare and endangered taxa, communities and ecosystems;

- reservation function defining the role of protected areas as areas of reproduction of plant and animal taxa that have economic value, and preservation of large animal clusters;

- "monumental" function, defined by the presence on PAs of particularly remarkable objects

- eco-stabilizing function, that consists in providing by protected areas of various kinds of ecosystem services significant for surrounding, and (or) for more remote areas.

The flow of environment forming services generated during the implementation of environmental protection functions of protected areas includes:

- services for the conservation of biological diversity (implementation of the standard, refugium, "monumental" and reservation functions);

- regulating (climate-regulating, stabilization of atmospheric composition, regulation of surface runoff, regulation of cryogenic processes, assimilation etc.) and protective (anti-erosion, soil protection, coast - and slope protection, thermal insulating etc.) eco-stabilizing ecosystem services (implementation of eco-stabilizing function).

Various types of protected areas carry out various environmental functions, depending on the tasks facing them [3]. Table 1 shows the data of the expert evaluation of the nature-protective functions and environmental services provided by nature reserves, national (natural) parks, wildlife sanctuaries, nature monuments. Due to priority of performing by protected areas of environmental functions, along with the provision of recreational, resource and information services, the primal subject of economic evaluation are ecosystem services provided by protected areas within the implementation of environmental protection functions

Analysis of methodological materials on the economic evaluation of protected areas shows that for their evaluation researchers currently use two methodological approaches [4]: the direct method of economic evaluation when the evaluation is done every kind of for provided goods and services $[1,5,6]$; and a mixed method (combined), when direct cost evaluation is complemented by the correction coefficients reflecting the quality characteristics of evaluated objects $[7,8]$. In the first recommendations on the economic evaluation of lands of reserve purposes, related to the beginning of the XXI century, the subject of evaluation, as in the following methodological recommendations, are the environment-forming services formed during the implementation of environmental protection functions of protected areas. In 2002, a feasibility study (FS) of methods of state cadastral evaluation of reservation lands [7] was published in the materials of the results of the GEF project «Biodiversity Conservation in the Russian Federation», in pursuance of the requirements of the Convention on Biological Diversity [9] and the tasks related to the necessity of optimization of a network of national parks and reserves [10]

Methodical approach [7] focuses on accounting of the opportunity cost, which acts as the value of gross output, obtained by the economic use of land that the society refuses to use, preferring the protection of natural ecosystems and the withdrawal of lands for nature reserves. In the first stage, researchers define the standard of the average value of lands of natural ecosystems, which in this case is the average level of the cadastral value of the land area of the reserve per unit generally for Russia. Further, based on the data of territory zoning by the main ecosystem types, researchers introduce the correction factors in the calculation:

- the value of ecosystems coefficient $\left(K_{v}\right)$, which characterizes the execution of biosphere functions by ecosystems of protected areas;

- biodiversity uniqueness coefficient $\left(K_{\mathrm{u}}\right)$, which reflects the unique biota of protected areas.

A little later there was a "Temporary procedure of state cadastral valuation of lands of specially protected areas and objects" (2004) [8], which regulates the procedure for determining the cadastral value of lands within the specially protected areas (SPAs) and objects specified by art. 94-100 of Land Code of the Russian Federation. In June 2015 the Ministry of Economic Development and Trade, by order № 138 approved methodical recommendations for state cadastral evaluation of lands of specially protected areas and objects. Practically, the order for calculating in procedure [8] remains unchanged: one takes the specific index of the cadastral value of land of protected areas, corrects it by using the correction coefficients and multiplies by the area of protected areas. Among the correction coefficients, in the same manner as in the procedure [7], are the ecosystem value coefficient for the dominant type of ecosystem of lands of protected areas, biodiversity uniqueness coefficient for the type of ecosystem that dominates on the land of protected areas. For specially protected areas (SPAs) of the first group, including the protected areas, the specific index of the cadastral value of land corresponds to the cadastral value of the $i$-th type of land (e. g. forest land, agricultura land, etc.), occupying the largest specific weight in the structure of this land. Each of the procedures has its own advantages and disadvantages. Therefore, if the first of them [7] covers land reserves, the second [8] covers the entire list of specially protected areas. At the same time, reserves are the specially protected areas of the first group, the calculation of the cadastral value of the land of which has same type, i. e., guidelines [7] are also useful in relation to all protected areas belonging to the first group of specially protected areas. Secondly, in the technique [8], the specific index of the cadastral value is calculated based on the rental approach to economic evaluation of land, which is why this technique is, as mentioned previously "accepted for state cadastral valuation of lands of specially protected areas and objects for tax purposes and is not applicable to account for values of specially protected natural areas as part of the national wealth, for the calculation of claims for damages and compensation payments" [11]. In turn, the technique [7] for the economic valuation of land uses the opportunity cost approach, which reflects the value of domestic product, produced by the region per unit area (income determined based on the economic territory of productivity) that allows authors to recommend its use for solving a wider range of tasks than simply taxation [7]. In addition, the use of the opportunity cost approach makes possible the formation of correction coefficients not only for the ecosystem type, but also for Russian Federation constituent members. 
Table 1. Environmental protection and environment-forming functions of protected areas services.

\begin{tabular}{|c|c|c|c|c|c|c|c|c|}
\hline \multirow{3}{*}{ Service names } & \multicolumn{8}{|c|}{ Protected area type } \\
\hline & \multicolumn{2}{|c|}{ Reserve } & \multicolumn{4}{|c|}{ National park, nature park } & \multirow[b]{2}{*}{$\begin{array}{l}\text { Wildlife } \\
\text { sanctuary }\end{array}$} & \multirow[b]{2}{*}{$\begin{array}{l}\text { Nature } \\
\text { monument }\end{array}$} \\
\hline & reserve area & $\begin{array}{c}\text { economic } \\
\text { purpose area }\end{array}$ & reserve area & $\begin{array}{l}\text { specially protected } \\
\text { area }\end{array}$ & $\begin{array}{l}\text { recreation } \\
\text { area }\end{array}$ & $\begin{array}{c}\text { economic } \\
\text { purpose area }\end{array}$ & & \\
\hline \multicolumn{9}{|l|}{$\begin{array}{l}\text { Environment forming } \\
\text { services }\end{array}$} \\
\hline $\begin{array}{r}\text { 1. Protection of biodiversity: } \\
\text { standard }\end{array}$ & ++ & & ++ & ++ & + & & & \\
\hline refugium & & & & & & & ++ & \\
\hline reservation & & & & & & & ++ & \\
\hline «monumental» & & & & & & & & ++ \\
\hline $\begin{array}{l}\text { 2. Ecological-stabilization } \\
\text { services: }\end{array}$ & ++ & + & ++ & ++ & ++ & + & ++ & + \\
\hline \multicolumn{9}{|l|}{ Regulating } \\
\hline \multicolumn{9}{|l|}{ climate regulation } \\
\hline \multicolumn{9}{|l|}{$\begin{array}{r}\text { regulation } \\
\text { of surface runoff }\end{array}$} \\
\hline \multicolumn{9}{|l|}{$\begin{array}{r}\text { composition } \\
\text { and others }\end{array}$} \\
\hline \multicolumn{9}{|l|}{ Protective } \\
\hline \multicolumn{9}{|l|}{ soil protection } \\
\hline thermal insulation & & & & & & & & \\
\hline $\begin{array}{r}\text { anti-erosion } \\
\text { and others }\end{array}$ & & & & & & & & \\
\hline
\end{tabular}

Note: ++ - high importance; + - average importance.

Third, the correction coefficients of value of ecosystems and biodiversity uniqueness, used in techniques, have a complete explanation of its calculation in technique [7], while in the Temporary procedure [8] they do not have any explanation. Besides, the biodiversity uniqueness coefficients correspond to the similar ones in technique [7], but the coefficients of value of ecosystems are increased by $7,14-7,15$ times. The logic of this introduction of correction coefficients is unclear.

The authors suggest guidelines for the economic evaluation of protected areas, implementing environmental protection functions, suggest the use of a number of methodological approaches, taking place in considered techniques $[7,8]$. We consider it appropriate to use the methodological provisions set out in [7] concerning the definition of the standard average value of unit area of the reserve lands for the Russian Federation as a whole, differentiation of which we carry out using correction coefficients. Authors determined the standard average values of land reserves [7] based on the statistically established patterns linking the decline of economic productivity of territories with an increase of the area, which society accepts to withdraw from the economic circulation to create a reserve. Within the framework of this approach, the authors perceive the average value of domestic product, produced per unit area of the region, as the "opportunity cost» of public profit, created by the reserve lands ecosystems.

The value of the standard average value of land reserves $\left(C_{\mathrm{sp}}\right)$ for 2000 is defined in [7] at a rate of $26980 \mathrm{rub}$./year at a rate of capitalization equal to 0.012 . Then the annual standard average value of land reserves at the level of $2000\left(C_{\mathrm{sp}(2000)}\right)$ will be $323.76 \mathrm{rub} . / \mathrm{ha}$., and, taking into account the correction coefficient on the change of the country's GDP $\left(K_{\mathrm{GDP}}\right)$ equal to 10.05 for 2014 , the level will be:

$$
C_{\mathrm{sp}(2014)}=C_{\mathrm{sp}(2000)} K_{\mathrm{GDP}}=323,76 \frac{\mathrm{GDP}_{2014}}{\mathrm{GDP}_{2000}}=323,76 \cdot 10,05=3253,78 \mathrm{rub} . / \text { ha. }
$$

Among the correction factors, apart from the value of ecosystem coefficient $\left(K_{\mathrm{v}}\right)$, and the biodiversity uniqueness coefficient $K_{\mathrm{u}}$, the value of which is given in Annexes 1-5 [7], authors recommend to take into account a number of additional correction coefficients:

- the coefficient of environmental protection value of $i$-th functional PA $\left(K_{f}\right)$, which reflects the different significance of implementation of environmental protection features within the $i$-th functional PA;

- PAs biodiversity uniqueness coefficient at the regional level $\left(K_{\mathrm{bu}}\right)$, which is calculated by the proportion of rare species of plants and animals listed in the Red Book of the region;

- the coefficient of environmental protection significance of PAs $\left(K_{\mathrm{ps}}\right)$, reflecting the rarity of ecosystems, taking into account the level which corresponds to the estimated PA.

In general, the recommended calculation formula for economic evaluation of protected areas, implementing environmental protection functions will be:

$$
O_{\mathrm{PA}}=\left[C_{\mathrm{sp}} K_{\mathrm{v}} K_{\mathrm{u}} K_{\mathrm{bu}} K_{\mathrm{ps}}\left(\sum_{i=1}^{m} \mathrm{P}_{i} \cdot K_{\mathrm{fi}}\right)\right] S_{\mathrm{PA}}, \text { rub. / year, }
$$

where $O_{\mathrm{PA}}$ is the annual economic evaluation of protected areas, rub./year; $C_{\mathrm{sp}}$ - the annual standard average land value of protected areas at the time of evaluation, taking into account the correction factor $\left(K_{\mathrm{GDP}}\right)$ of change the country's GDP, rub./ha; $P_{i}$ - the part of the $i$-th functional zone in the total area of PAs, unit parts; $i-$ functional zone $(i=1 \ldots m) ; S_{\mathrm{PA}}$ - the total area of PAs, ha.

The economic estimation of the specific PA represented by several ecosystem types requires calculation of the averaged value of the value of ecosystem coefficient that takes into account the proportion of the area of each ecosystem type in the total area of natural complex of PAs, and the values of the correction coefficients [7]:

$$
K_{\mathrm{v}}=\sum_{j=1}^{N} K_{\mathrm{v} j} P_{j}
$$

where $K_{\mathrm{v} j}$ is the coefficient of value of $j$ ecosystem type; $P_{j}-$ the proportion of $j$ type of ecosystem in the total area of PAs, unit parts; $j$ - ecosystem type $(j=1 \ldots N) ; N$ - number of ecosystem types.

Introduction of the coefficient of environmental protection values of functional zones $\left(K_{\mathrm{fi}}\right)$ is due to the different significance of the implementation of environmental protection functions in a particular area (for example, services provided in the economic purpose area by performing natural and economic functions will be significantly lower than in reserve, specially protected area, and so on). Justification of the value of the correction factor requires allocation of functional zones composed of different types of PAs. Based on the analysis of materials on functional zoning of PAs of Khanty-Mansi Autonomous District (KhMAD), Yamalo-Nenets Autonomous District, Murmansk Region, Republic of Karelia, Republic of Komi, Kamchatka authors justified average structure 
of functional zones for national and natural parks

Table 2 shows the proposed correction factors of conservation value of functional zones.
Table 3 shows recommended rates of environmental significance of protected areas, reflecting the scale of the ecosystems rarity, taking into account the level that corresponds to the estimated PA.

\begin{tabular}{|c|c|}
\hline 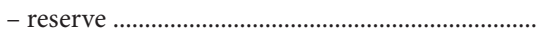 & $-15 \%$ of PAs; \\
\hline - specially protected area ........................................... & $-35 \%$ of PAs; \\
\hline - traditional nature area (ancestral lands) ........... & $-15 \%$ of PAs; \\
\hline - recreation area & $\begin{array}{l}\text { - 30\% of PAs (its basic service objects are located in the protected areas } \\
\text { or concentrated in nearest settlements); }\end{array}$ \\
\hline 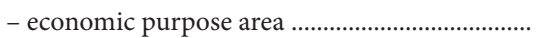 & $-5 \%$ of PAs. \\
\hline
\end{tabular}

The coefficient of biodiversity uniqueness at the regional level researchers establish based on information on the most vulnerable part of species diversity, listed in the Red Book of the region.

The authors tested the proposed methodic recommendations for the conditions of the mountainous part of the KhMAD - Yugra within the boundaries of the district Berezovskiy. The object of evaluation is the mountainous part of the county, represented by North (970 ths ha) and Polar Urals (2230 ths ha) with adjacent foothill areas.

To justify value of the value of ecosystem coefficient $\left(K_{\mathrm{v}}\right)$ the authors analyzed types of plant complexes on the territory of object of evaluation - east

Table 2. Functional zones and conservation value coefficient.

\begin{tabular}{lc}
\hline \multicolumn{1}{c}{ Type of protected areas and types of zones } & The value of $K_{\mathrm{fi}}$ \\
\hline Reserve areas: & 1,0 \\
national parks, nature parks & 1,0 \\
reserved, specially protected area & 0,9 \\
traditional nature area & 0,8 \\
recreation area (area of regulated recreational visiting) & 0,5 \\
economic purpose area & \\
Wildlife sanctuaries: & 1,0 \\
complex (landscape) with land withdrawal & 0,8 \\
complex (landscape) without land withdrawal & 0,9 \\
the remaining (except complex) with land withdrawal & 0,7 \\
the remaining (except complex) without land withdrawal & 1,0 \\
Nature monuments & \\
\hline
\end{tabular}

Table 3. The coefficients of environmental significance of protected areas.

\begin{tabular}{lc}
\hline \multicolumn{1}{c}{ The importance of protected areas } & $\begin{array}{c}\text { Value of the } \\
\text { coefficient } K_{\mathrm{ps}}\end{array}$ \\
\hline The international Natural Heritage (in the lists of PAs of & 2,00 \\
international importance) & 1,50 \\
Russian National Heritage (federal PAs) & 1,25 \\
Heritage of a number of Russian regions & 1,00 \\
Heritage of the region of Russian Federation (regional PAs) & \\
\hline
\end{tabular}

macroslope of Northern and Polar Urals within the boundaries of Berezovskiy district of KhMAD - Ugra with surrounding foothill areas.

Within the mountain slopes of estimated territories are the following high-altitude vegetation belts: mountain forest, subalpine, mountain-tundra, belt of alpine cold deserts [12]. The structure of the vegetation cover of the assessment object is characterized by the geobotanical map of scale 1:2,500,000, composed by K. N. Igoshina [13], which shows 11 kinds of vegetable complexes (with retaining the numbers of original legend):

3 - bushy tundra, flat hilly marshes, and willow coppices;

4 - alpines (mountain-tundra belt and a belt of alpine cold deserts) in [12];

5 - larch forests and woodlands, interspersed with spruce forests;

6 - birch-spruce sparse forests;

7 - secondary forests in place of dark coniferous forests (on burned areas);

8 - birch-spruce forests of northern taiga;

14 - pine forests of northern taiga;

16 - secondary forests in place of pine forests (on burned areas);

19 - forests with a predominance or noticeable admixture of cedar

20 - secondary birch forests;

$20 \mathrm{p}$ - primary mountain sparse birch forests

24 - swamps.

Vegetable complexes shown on the map of K. N. Igoshina the authors divided into four groups corresponding to the ecosystem types, presented in the Annexes 4 [7] and 5 [1] (Table 4).

Table 5 calculated the coefficients of value of ecosystems for conditions of Northern and Polar Urals based on the availability of ecosystem types and their distribution area.

Thus, the calculated value of ecosystems coefficients (Table 5), are weighted average by the ecosystem types: for the Northern Urals $K=1.0974$ for the Subpolar Urals $K_{v}=1,081$. These coefficients were adjusted on the basis of expert assessments that take into account the contribution of each ecosystem type in the implementation of prior for the given territory ecologicalstabilization services. The calculations resulted in the following values of the coefficients: for the Northern Urals $=1.17$, for the Subpolar Urals $=1.12$.

The coefficient of biodiversity uniqueness researchers determined by direct calculations by accessing the Red Book of the Russian Federation [14] (Table 6).

The coefficient of $\left(K_{\mathrm{bu}}\right)$, which reflects the uniqueness and specificity of species diversity at the regional level was established based on the analysis of the regional Red Book of KhMAD - Ugra [15]. This paper assembles information on the most vulnerable part of the species diversity of the district in need of protection. The results of calculations of regional uniqueness coefficient are in Table 7.

\section{Table 4. Ecosystem types.}

\begin{tabular}{|c|c|c|c|}
\hline \multicolumn{2}{|c|}{ Ecosystem types on the Annexes 4 [7] and 5 [1] } & \multirow{2}{*}{$\begin{array}{l}\text { Number of the legend of the geobotanical map } \\
\text { (Igoshina, 1963) }\end{array}$} & \multirow{2}{*}{ High-altitude belts } \\
\hline Ecosystem types & Ecosystem characteristics & & \\
\hline 1a. Polar desert & $\begin{array}{l}\text { Stony, lichen and moss-lichen } \\
\text { with fragments of algal crusts }\end{array}$ & 4. Alpines & $\begin{array}{l}\text { The belt of alpine cold deserts } \\
\text { and mountain-tundra belt }\end{array}$ \\
\hline $\begin{array}{l}\text { 16б. Polar Ural tundra } \\
\text { forest }\end{array}$ & Mountain tundra woodlands & $\begin{array}{l}\text { 3. Bushy tundra, flat hilly marshes, and willow coppices } \\
\text { 20p. Primary mountain sparse birch forests }\end{array}$ & $\begin{array}{l}\text { Mountain tundra } \\
\text { and subalpine belts }\end{array}$ \\
\hline 17a. North Urals & $\begin{array}{l}\text { Mountain-taiga spruce-fir } \\
\text { and cedar-fir forests } \\
\text { and light forests }\end{array}$ & $\begin{array}{l}\text { 5. Larch forests and woodlands, interspersed with spruce forests } \\
\text { 6. Birch-spruce sparse forests } \\
\text { 7. Secondary forests in place of dark coniferous forests (on } \\
\text { burned areas) } \\
\text { 8. Birch-spruce forests of northern taiga } \\
\text { 16. Secondary forests in place of pine forests (on burned areas) } \\
\text { 19. Forests with a predominance or noticeable admixture of cedar } \\
\text { 20. Secondary birch forests }\end{array}$ & $\begin{array}{l}\text { Subalpine and mountain } \\
\text { forest belts }\end{array}$ \\
\hline 6в. Northern taiga & $\begin{array}{l}\text { Larch, pine-larch, spruce-larch } \\
\text { with cedar, moss forests and hilly } \\
\text { swamps }\end{array}$ & 14. Pine forests of northern taiga & Foothill territories \\
\hline
\end{tabular}

Note. Due to not entirely successful development of the annexes 4 [7] and 5 [1], a division of vegetation in mountain belts of Polar Urals is practically impossible to implement, because Polar Urals is simply absent in the specified annexes: the Polar Urals «tundra forest» (166) in Annex 5 [1] (map chart) borders the Northern Urals (17a). No matching ecosystem types in Annex 4 [7]. There are no characteristics of vegetation of belt of alpine cold deserts in these annexes; therefore, authors used assessment of plain polar deserts. 
Table 5. The calculation of the coefficient of value of ecosystems.

\begin{tabular}{|c|c|c|c|c|}
\hline $\begin{array}{l}\text { Ecosystem types on the } \\
\text { Annexes } 4 \text { [7] and } 5 \text { [1] }\end{array}$ & $\begin{array}{c}\text { № of the legend of the geobotanical } \\
\text { map (Igoshina, 1963) }\end{array}$ & $\begin{array}{c}K_{v} \\
\text { (Annex } 4[7])\end{array}$ & $\begin{array}{c}\text { The proportion of ecosystems } \\
\text { type of the total area }\end{array}$ & $\begin{array}{l}K_{v} \text { for ecosystems, taking into } \\
\text { account the relative area }\end{array}$ \\
\hline \multicolumn{5}{|c|}{ Northern Urals } \\
\hline $1 \mathrm{a}$ & 4 & 0,43 & 0,07 & 0,0301 \\
\hline 166 & $3,20 p, 24$ & 0,89 & 0,07 & 0,0623 \\
\hline $17 a$ & $5,6,7,8,16,19,20$ & 1,25 & 0,61 & 0,7625 \\
\hline $6 \mathrm{~B}$ & 14 & 0,97 & 0,25 & 0,2425 \\
\hline Total & & & 1 & 1,0974 \\
\hline \multicolumn{5}{|c|}{ Subpolar Urals } \\
\hline $1 \mathrm{a}$ & 4 & 0,43 & 0,15 & 0,0645 \\
\hline 166 & $3,20 p, 24$ & 0,89 & 0,05 & 0,0445 \\
\hline $17 a$ & $5,6,7,8,16,19,20$ & 1,25 & 0,70 & 0,875 \\
\hline $6 \mathrm{~B}$ & 14 & 0,97 & 0,10 & 0,097 \\
\hline Total & & & 1 & 1,081 \\
\hline
\end{tabular}

Table 6. The coefficients of biodiversity uniqueness on the territory of Northern and Subpolar Urals, at the federal level.

\begin{tabular}{|c|c|c|c|c|c|c|}
\hline \multirow[b]{2}{*}{ Objects of protection } & \multicolumn{3}{|c|}{ Northern Urals } & \multicolumn{3}{|c|}{ Subpolar Urals } \\
\hline & $\begin{array}{l}\text { Number } \\
\text { of species }\end{array}$ & $\begin{array}{l}\text { The number of species } \\
\text { in the Red Book of the } \\
\text { Russian Federation }\end{array}$ & $\begin{array}{c}\text { The proportion } \\
\text { of species }\end{array}$ & Number of species & $\begin{array}{c}\text { The number of species in } \\
\text { the Red Book of the Russian } \\
\text { Federation }\end{array}$ & $\begin{array}{c}\text { The proportion } \\
\text { of species }\end{array}$ \\
\hline Mammals & 46 & 0 & 0 & 37 & 0 & 0 \\
\hline Birds & 176 & 4 & 0,023 & 146 & 4 & 0,027 \\
\hline Fish and lampreys & 25 & 1 & 0,04 & 25 & 1 & 0,04 \\
\hline Plants & 600 & 3 & 0,005 & 500 & 2 & 0,004 \\
\hline$K_{\text {bu }}$ & & $1+0,07$ & & & $1+0,07$ & \\
\hline
\end{tabular}

Table 7. Calculation of the coefficient of biodiversity uniqueness of mountain territory KhMAD-Ugra at the regional level of $K_{\mathrm{bu}}$.

\begin{tabular}{|c|c|c|c|c|c|c|}
\hline \multirow[b]{2}{*}{ Objects of protection } & \multicolumn{3}{|c|}{ Northern Urals } & \multicolumn{3}{|c|}{ Subpolar Urals } \\
\hline & $\begin{array}{l}\text { Number } \\
\text { of species }\end{array}$ & $\begin{array}{c}\text { The number } \\
\text { of species in the Red } \\
\text { Book of KhMAD (2013) }\end{array}$ & $\begin{array}{l}\text { The proportion } \\
\text { of species from the Red Book } \\
\text { of KhMAD from total number }\end{array}$ & $\begin{array}{l}\text { Number } \\
\text { of species }\end{array}$ & $\begin{array}{c}\text { The number } \\
\text { of species in the Red } \\
\text { Book of hMAD (2013) }\end{array}$ & $\begin{array}{l}\text { The proportion } \\
\text { of species from the Red Book } \\
\text { of KhMAD from total number }\end{array}$ \\
\hline Lampreys & $1^{*}$ & 0 & 0 & 1 & 0 & 0 \\
\hline Fish & $24^{*}$ & 1 & 0,04 & 24 & 1 & 0,04 \\
\hline Amphibia & $5^{*}$ & 1 & 0,20 & 4 & 1 & 0,25 \\
\hline Birds & $98^{*}$ & 12 & 0,12 & 97 & 12 & 0,12 \\
\hline Mammals & $46^{*}$ & 2 & 0,04 & 37 & 3 & 0,08 \\
\hline Vascular plants & $600^{* *}$ & 62 & 0,10 & $500^{* *}$ & 60 & 0,12 \\
\hline Lichens & $300^{* *}$ & 21 & 0,07 & $310^{* *}$ & 20 & 0,06 \\
\hline Sum of proportions & & & 0,57 & & & 0,67 \\
\hline$K_{\text {bu }}$ & \multicolumn{3}{|c|}{$1+0,52=1,57$} & \multicolumn{3}{|c|}{$1+0,63=1,67$} \\
\hline
\end{tabular}

* The total number of species of lampreys, bony fish, amphibians, birds and mammals of the eastern slope of the Northern and Subpolar Urals given by [16];

** the total number of species of vascular plants and lichens (expert evaluation).

Thus, the biodiversity uniqueness coefficient at the regional level is much higher of such a ratio at the federal level, it is $\mathbf{1 . 5 7}$ for the Northern Urals, and $\mathbf{1 . 6 7}$ for the Subpolar Urals. The introduction of these coefficients in the formula for calculating the specific economic evaluation of prospective lands for creating protected areas increases their value.

The value of the coefficient of environmental significance $K_{\mathrm{ps}}$ at this stage of the calculation the authors take equal to one, and the annual standard average value of lands $\left(C_{\mathrm{sp}}\right)$ for $2014,-3253.78 \mathrm{rub}$./ha. Then, provided the organization in the future within the estimated territory of natural parks of regional importance with the appropriate for them average structure of functional areas based on the formula (1), the specific economic evaluation of protected areas will be:

For the Northern Urals = $5755.72 \mathrm{rub} . / \mathrm{ha}$;

For the Subpolar Urals $=5860.70 \mathrm{rub} . / \mathrm{ha}$.

Conclusions

We consider a methodical approach that combines direct assessment method (opportunity cost) and indirect (the introduction of correction factors to reflect qualitative characteristics of PA) as the most appropriate for the economic evaluation of protected areas, implementing environmental functions.

2. The uniqueness and specificity of the local flora and fauna, the degree of environmental protection services flow rates in the functional areas of protected areas, and environmental protection value of PAs are encouraged to consider using additional correction factors.

The values obtained for the specific economic evaluation of natural complexes of the eastern macroslope of Northern and Subpolar Urals within the boundaries of Berezovskiy district of KhMAD - Ugra are useful for ecological-economic feasibility of the natural parks of regional importance (North-Ural and Maninskiy).

\section{REFERENCES}

1. Fomenko G. A. et al. 2010, Ekonomicheskaya otsenka osobo okhranyaemykh territoriy Kamchatki: prakticheskie rezul'taty $i$ ikh znachenie dlya sokhraneniya bioraznoobraziya (na primere prirodnogo parka "Bystrinskiy») [Economic valuation of protected areas of Kamchatka: the practical results and their implications for the conservation of biodiversity (on example of a Natural park «Bystrinsky»)], Yaroslavl', $156 \mathrm{p}$.

2. Stishov M. S. 2012, Metodika otsenki prirodookhrannoy effektivnosti osobo okhranyaemykh prirodnykh territoriy $i$ ikh regional'nykh sistem [Methods of assessing of the environmental effectiveness of protected areas and their regional systems], Moscow, 284 p.

3. Litvinova A. A., Ignat'eva M. N., Koroteev N. D. 2016, Identifikatsiya uslug, predostavlyaemykh osobo okhranyaemymi prirodnymi territoriyami [Identification of the services provided by protected areas]. Uspekhi sovremennogo estestvoznaniya [Advances in current natural sciences], no. 6, pp. 164-168.

4. Litvinova A. A., Ignat'eva M. N. 2015, Metodicheskie podkhody k obosnovaniyu sozdaniya osobo okhranyaemykh prirodnykh territoriy [Methodological approaches to justification of creation of protected areas]. Agrarnyy vestnik Urala [Agrarian Bulletin of the Urals], vol. 140, no. 10, pp. 83-85.

5. Tishkov A.A. 2002, Ekonomika sokhraneniya bioraznoobraziya [Economics of biodiversity conservation], Moscow, $604 \mathrm{p}$.

6. Ekhanurova E. A. 2005, Otsenka ekologicheskikh vygod na territorii s osobym rezhimom prirodopol'zovaniya [Assessment of environmental benefits on the ter- 
ritory with a special regime nature management]. Ekonomika prirodopol'zovaniya [Environmental economics], no. 4, pp. 29-55.

7. 2002, Tekhniko-ekonomicheskoe obosnovanie metodiki gosudarstvennoy kadastrovoy otsenki zemel' zapovednikov. Novye finansovye mekhanizmy sokhraneniya bioraznoobraziya: $k$ itogam Proekta GEF «Sokhranenie bioraznoobraziya $v$ Rossiyskoy Federatsii» [Feasibility study of methodology of state cadastral valuation of lands reservations. New financial mechanisms of biodiversity conservation: to the results of the GEF Project «Biodiversity Conservation in the Russian Federation»], Moscow pp. 156-185

8. 2004, Vremennaya metodika gosudarstvennoy kadastrovoy otsenki zemel' okhranyaemykh territoriy i ob'ektov [Provisional guidelines state cadastral valuation of protected areas and objects], Moscow, $25 \mathrm{p}$.

9. Konventsiya o biologicheskom raznoobrazii [The Convention on Biological Diversity]. Available at: http://www.un.org/ru/documents/decl_conv/conventions/ biodiv.shtml

10. Ukaz Prezidenta RF «Ob osobo okhranyaemykh prirodnykh territoriyakh RF» ot 02.10.1992 № 1155 [Presidential Decree «On specially protected natural territories of the Russian Federation» dated 02.10.1992 № 1155].

11. 2004, Metodika gosudarstvennoy kadastrovoy otsenki osobo okhranyaemykh prirodnykh territoriy i ob'ektov [Method of state cadastral estimation of specially protected natural territories and objects], Moscow, $10 \mathrm{p}$.

12. Gorchakovskiy P. L. 1975, Rastitel'nyy mir vysokogornogo Urala [Flora of the Urals Mountains], Moscow, $283 \mathrm{p}$.

13. Igoshina K. N. 1964, Karta rastitel'nosti Urala M 1: 2500000 (1963). Rastitel'nost' SSSR i zarubezhnykh stran [Vegetation Map of Ural 1: 2500000 (1963) Vegetation of the USSR and foreign countries]. Trudy BINa. Seriya III. Geobotanika [Proceedings of Botanical Institute. Third Series. Geobotany], Moscow, pp. 83-230. 14. Trutnev Yu. P., Kamelin R. V., et al. 2008, Krasnaya kniga Rossiyskoy Federatsii (rasteniya $i$ griby) [The Red Book of the Russian Federation (plants and fungi)], Moscow, $855 \mathrm{p}$

15. Vasin A. M., Vasina A. L., 2013, Krasnaya kniga Khanty-Mansiyskogo avtonomnogo okruga - Yugry: zhivotnye, rasteniya, griby [The Red Book of the Khanty-Mansi Autonomous District - Yugra: animals, plants, fungi], Ekaterinburg, $460 \mathrm{p}$. 16. Ryzhanovskiy V. N., Bogdanov V. D. 2013, Katalog pozvonochnykh zhivotnykh gorno-ravninnoy strany Ural: Annotirovannyy spisok i regional'noe raspredelenie. Spravochnoe posobie [Catalog of vertebrate animals of mountain-plain country Ural: Annotated list and regional distribution. A Reference guide], $172 \mathrm{p}$.

Mikhail Sergeevich Kubarev,

Kubarev_mc@mail.ru

Ural State University of Economics

Ekaterinburg, Russia

albalit2012@yandex.ru

Margarita Nikolaevna Ignat'eva,

Institute of Economics of the Ural Branch of the RAS

Ekaterinburg, Russia

Lyudmila Mikhaylovna Morozova,

morozova@ipae.uran.ru

Institute of Plants and Animals Ecology of the Ural Branch of the RAS

Ekaterinburg, Russia 